\title{
Covid-19 Pandemic and its Effect on Indian Industry
}

\author{
V. Pradeepa \\ Assistant Professor in Commerce, APA College of Arts \& Culture, Palani, Tamil Nadu, India \\ D https://orcid.org/0000-0002-1380-2622
}

\begin{abstract}
The outbreak of the COVID-19 pandemic is a completely unexpected shock to the economy. The Government of India has announced measures like food security and healthcare measures, incentives to a few sectors, tax deadline extensions, housing loan moratorium scheme, time extension for electricity bill payment, cancellation, postponement of examinations, etc. to tackle this pandemic situation. With the extension of the country wide lockdown, the global economic downturn and related disruption of demand and supply chains, the economy is likely to face a protracted slowdown. This study focused on the impact of the pandemic on various sectors like manufacturing industries, banking, real estate, textile, agriculture, education, healthcare, electronics, and services. The effect of COVID-19 is going to last for quite some time, even though primary activities and industries have resumed their routine work.
\end{abstract}

\section{OPEN ACCESS}

Manuscript ID:

COM-2021-09013512

Volume: 9

Issue: 1

Month: January

Year: 2021

E-ISSN: 2582-6190

Received: 28.10 .2020

Accepted: 01.12.2020

Published: 01.01.2021

Citation:

Pradeepa, V. "Covid-19

Pandemic and Its Effect on Indian Industry." ComFin

Research, vol. 9, no. 1, 2021, pp. 22-25.

DOI:

https://doi.org/10.34293/

commerce.v9i1.3512

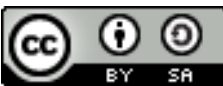

This work is licensed under a Creative Commons Attribution-ShareAlike 4.0 International License

Keywords: COVID-19, Pandemic, Whole economy, Economic downturn, Impact and Moratorium

\section{Introduction}

Globally, the epidemic has produced an unstable environment. The world is facing the biggest crisis and has stopped many of its economic activities. The spread of COVID-19 across the globe has drastically affected many sectors. The Indian economy is facing many new challenges now, like the severe disruption of demand and supply chain, which can block India's growth because of the pandemic. The impact of the epidemic on the Indian economy could be significant and have a long-lasting effect. The corona virus has affected the human population in almost every possible way. According to the Ministry of Statistics, India's growth went down to $3.1 \%$ in the fourth quarter of 2020 . This drop is mainly due to the impact of the COVID-19 pandemic on the Indian economy, as stated by the Chief Economic Adviser, The Government of India. Health, Economy, Industry, Food, and every possible sector are prejudiced because of restrictions. The impact is so intense that, along with a threat to health, it has become an even significant threat to the global economy.

\section{Objectives of the Study}

- To understand the effects of Coronavirus (COVID-19) on the Indian industry.

- To study the impact of COVID-19 on different sectors of the Indian economy.

- To find out the challenges of different sectors in the Indian economy. 


\section{Literature Review}

ANAROCK Research, 2020 traces the impact of COVID-19 on the Indian real estate sector. It discloses that the sector was on a growth track over the last few years and was likely to emerge even stronger than before, but the current COVID-19 lockdown has certainly reined in its growth phase. The study analyses market size and GDP, employment, and foreign direct investment in the Indian real estate market. The study also discusses the effect of COVID-19 on the Indian commercial office sector and Indian residential retail sector. It indicates that diminishing Indian economic growth and a sharp reaction by global economies to the ongoing pandemic will influence the Indian office segment and bring the residential real estate business to a standstill. Finally, the report states that to beat any crisis, all industries must revamp and rectify their built-in flaws.

Ozili P., and Thankom A. (2020) had highlighted the spillovers of COVID - 19 on the global economy. It tries to highlight the impact of Coronavirus on different sectors of the economy like the sports industry, travel industry, hospitality industry, oil price war among countries, financial sector, import-dependent countries, education sector, health sector, and the entertainment sector. The study also discusses how to avoid the severe impact of the disease spreading virus all over the world by introducing fast policy responses by policymakers. The paper emphasizes the recession faced by most of the countries, and almost all the nations followed the trade-off between saving the life of people and saving the economy on the whole. The study concludes that the pandemic situation has made all countries improvise their healthcare sector and has led to a development phase in terms of online education, health and hygiene, pharmaceutical industries, online banking, online textile and cosmetic sale, and transportation systems.

Mahindra S. Dev and Rajeshwari Sengupta (2020) have highlighted the impact of Coronavirus on the overall economy by comparing the situations before the crisis and after the crisis. This paper focuses on coronavirus and its influence on the Informal sector, Banking sector, MSMEs, Financial markets, and limited policy space. The study explains and highlights the various policies announced by the Government to handle the current crisis and the successful implementation of such practices in the world. The paper also discusses how the worldwide lockdown has brought all the economic activities to a sudden halt and its spill over effects on employment, investment, income, and consumption. Finally, it has focussed on the measures adopted by the Reserve Bank of India, State, and Central Government to improve the economic conditions simultaneously at the same time controlling the virus.

\section{Effect of COVID-19 on Indian industry Agriculture Industry}

The nationwide lockdown has left farmers in trouble, especially during the harvest season. They find it extremely difficult to transport their products into markets. Many farmers have destroyed their products due to difficulty in transporting their products. They are severely affected, and this may lead to bankruptcies and, further, to farmer suicides.

\section{Textile Industry}

India mainly depends on China for textile raw materials like synthetic yarn, synthetic fabric, buttons, zippers, hangers, etc. At the same time, India exports cotton yarn to China in bulk quantities. But this lockdown has affected everything, and cotton prices have come down. In the same way, textile showrooms were also not able to open due to this pandemic. The pandemic hurts the import and export of textiles and the domestic market.

\section{Poultry Industry}

At the beginning of the pandemic, the poultry sector was drastically affected by a rumor spread on India's social media platforms. The talk was that the consumption of chicken would cause corona. This rumor put down the poultry sector, and the poultry sales crashed down by $80 \%$. Many of the poultry farms were closed, and they threw eggs onto the roadsides. This recent crisis has severely destabilized the sector, and poultry farmers have sought help from the Government to resolve this issue. The poultry industry has again started its business from the root and is reaching the normal situation before the pandemic. 


\section{Education Industry}

The education sector is one of the badly disturbed sectors in India due to Covid-19. The educational sector in the country is already in a miserable condition and has been undergoing a critically challenging phase. The Indian Government has announced a complete lockdown of schools and colleges in March 2020 and all other private and public organizations. Consequently, the academic year was suddenly interrupted at the time of a critical examination. Usually, the academic year starts in June every year and closes in March and April with the year-end or semester examinations. In schools and colleges, the dates of the examinations have been announced, postponed, and then canceled. The Tamil Nadu government had canceled the SSLC examination due to the epidemic. Universities and colleges used online platforms to conduct endsemester examinations for final year students and published the students' results quickly.

The government's decision regarding marks to be awarded needs to be acceptable to the larger student community, and the institutional authorities, academicians, teachers, and parents, etc. The inability of the students to be present for their examinations should not lead to psychological stigma in their minds. On the other hand, there is a possibility for the student's growth in their academic performance to be underestimated if they are promoted without examinations. An opportunity to test their academic performance may be lost if they do not appear for examinations.

The school education industry is still in a dilemma about restarting the next academic year and the kinds of changes to adopt in tackling the postCovid-19 scenario.

During this lockdown, due to the Covid-19 pandemic, online education is one of the most widely used methods in the educational sector in India as well as all over the world. Most educational institutions believe that online education is the only solution to continue the learning process in this critical situation.

Educational institutions, faculty, students, parents, and also governments are facing serious challenges in adapting to an online mode of teaching/ learning system. At the institutional level, the online education system has certain difficulties like lack of technical expertise, the infrastructure required like recording equipment, and studios, etc.

The dominant problem for individuals in the online learning system is the accessibility to the internet. A majority of students in rural areas do not have access to computers and laptops. The availability of smartphones is not of great advantage as internet connections are expensive and remote areas have issues about electricity and cell phone signals.

However, the substitution of the regular learning system with online education cannot be considered as a suitable mode of education. Still, the same can be considered as a supportive learning method. Since it involves several limitations, either the government or the educational institutions are not supposed to impose it forcefully.

\section{Healthcare Industry}

The emerge of COVID-19 has adversely affected all associated with medical tourism, be it healthcare providers or individuals seeking medical care. As India is facing continuous lockdown from the last week of March - 2020, medical tourism is severely affected due to the restriction of International aviation services and limited healthcare services. Many of the clinics were closed due to the fear of coronavirus spread as most doctors were under COVID-19 duty. Also, hospitals denied admission to new patients during the pandemic situation to avoid the risk of COVID-19 spread.

\section{Electronics Industry}

Prior to the pandemic, the electronics market witnessed a modest growth rate globally. But after the pandemic, the global electronics industry has faced a dual impact. The workforce unavailability and the slowdown of logistics have affected and reduced the production of electronics parts. On the other side, the stoppage of delivering non-essential items by e-companies worldwide has also affected the electronics industry. The sales of electronic products are expected to be further affected due to the total shutdown of retail shops and showrooms of all major brands, malls, supermarkets, and hypermarkets for a definite period. Apart from this, the global supply chain of major brands of electronic products was also 
disturbed by the pandemic. The key players of the market are taking the required measures to reduce the adverse impact of COVID-19.

\section{Conclusion}

The COVID-19 pandemic is a big challenge to humanity in all possible aspects. It has bought the World, Economy, and Industries to a standstill, even if for a while. Almost all nations are under lockdown, and International travel is also restricted. It is difficult to handle such a pandemic situation in a highly populated country like India. The Central and State Governments are putting their best efforts to bring this challenging situation to an end; the impact of COVID-19 will last for quite some time, even though primary activities and industries have started to resume their routine work.

\section{References}

COVID-19: Impact on the Indian RE Sector, ANAROCK, 2020.

Das, Kishore Kumar, and Shalini Patnaik. "The Impact of COVID-19 in Indian EconomyAn Empirical Study." International Journal of Electrical Engineering and Technology, vol. 11, no. 3, 2020, pp. 194-202.

Dev, Mahindra S., and Rajeshwari Sengupta. COVID-19: Impact on the Indian Economy, IG Institute of Development Research, 2020.

"Economic Impact of the COVID-19 Pandemic in India." Wikipedia.

Gupta, Achal. "India: Coronavirus (COVID-19) and Indian Economy." Mondaq, 2020.

https://www.mohfw.gov.in

"Impact of COVID-19 on the Global Electronics Industry, 2020." Research and Markets, 2020.

Jadhav, Girish. Impact of COVID-19 on Indian Industry: Challenges and Opportunities, 2020.

Kumar, S Udhaya, et al. "The Rise and Impact of COVID-19 in India." Frontiers in Medicine, 2020.

Kumar, Sunil, et al. "Impact of Coronavirus (COVID-19) on Indian Economy."
Agriculture \& Food: e-Newsletter, vol. 2, no. 4, 2020, pp. 301-302.

Mohan, Chander, et al. "Effect of Covid-19 on India." International Journal of Advanced Educational Research, vol. 5, no. 2, 2020, pp. 19-22.

Nair, Sangeeta. "Coronavirus Hotspots in India: Full list of 130 COVID-19 Hotspot Districts, All Metro cities Marked Red Zones." Jagran Josh, 2020.

Ozili, Peterson, and Thankom Arun. Spillover of COVID-19: Impact on the Global Economy, 2020.

Peeri, Noah C., et al. "The SARS, MERS and Novel Coronavirus (COVID-19) Epidemics, the Newest and Biggest Global Health Threats: What Lessons have we learned?." International Journal of Epidemiology, vol. 49, no. 3, 2020, pp. 717-726.

Sen, Srabani. "Indian Cholera: A Myth." Indian Journal of History of Science, vol. 47, no. 3, 2012, pp. 345-374

Sharma, Abhimanyu, et al. "Impact of COVID-19 Outbreak over Medical Tourism." IOSR Journal of Dental and Medical Sciences, vol. 19 , no. 5 , 2020 , pp. 56-58.

Smith, Richard D. "Responding to Global Infectious Disease Outbreaks: Lessons from SARS on the Role of Risk Perception, Communication and Management." Social Science \& Medicine, vol. 63, no. 12, 2006, pp. 3113 -3123.

Szlezak, Philipp-Carlsson, et al. "What Coronavirus could mean for the Global Economy." Harvard Business Review, 2020.

"The Social and Economic Impact of Covid-19 in the Asia-Pacific Region." UNDP, 2020.

"Trade Impact of Coronavirus for India Estimated at \$348 mn: UN report." The Hindu Business Line, 2020.

Wee, Sui-Lee, et al. "W.H.O. Declares Global Emergency as Wuhan Coronavirus Spreads." The New York Times, 2020.

\section{Author Details}

Dr. V. Pradeepa, Assistant Professor in Commerce, APA College of Arts \& Culture, Palani, Tamil Nadu, India,

Email ID: pradeepagovind@gmail.com 